\title{
Onderweg na 'n teologie van interkulturaliteit: 'n Trinitariese perspektief
}

R Venter

(Universiteit van die Vrystaat)

\section{ABSTRACT \\ Towards a theology of interculturality: A trinitarian perspective}

The greater interaction of people from diverse cultural orientation in a globalised era and the growth of the christian faith as a truly worldwide phenomenon, and the consequent complications have highlighted the need for a theological response. This paper explores such a proposal for intercultural encounter, especially among people of the same religious orientation. The emphasis is on transcendence, community and identity, or on trinity, church and spirituality. The fundamental assumption is that the trinitarian identification of God, with its concomitant stress on otherness, relationality and love, provides resources to guide intercultural challenges in the church. A consistent trinitarian approach values community; hence the imperative of a communio-ecclesiology, which embraces unity, creativity and social resistance. Identity-formation and spirituality are closely linked. A trinitarian approach advocates transformation which increasingly reflects the virtues of the triune God in the relationship with the culturally Other.

\section{INLEIDING}

Kulturele diversiteit word allerweë as een van die uitstaande kenmerke en uitdagings van die huidige globale samelewing uitgewys. Globalisasie werk nie net 'n verskerpte migrasie van mense in die hand nie, maar verhewig onvermydelik ook prosesse van interaksie. Postkoloniale sentimente van mense-regte en ' $n$ niehiërargiese waardering van kulture bring ' $\mathrm{n}$ verdere dimensie aan die nuwe horison van kontak. Binne die internasionale sakewêreld is die uitdaging vinnig bespeur en die aandag aan interkulturele kommunikasie was ' $n$ pro-aktiewe en natuurlike refleks. Die stroom van werk oor kruis- en interkulturele kommunikasie is ' $\mathrm{n}$ bewys hiervan. Die reaksie van die kerk en teologie binne hierdie horison is teleurstellend. Kulturele diversiteit, en die gesig van die "Ander", bring nie net ' $n$ huiwering nie, maar lei dikwels tot uitsluiting, diskriminasie en konflik (Case-Winters 2006:43). Die frusterende vordering met kerk-vereniging binne die Gereformeerde familie van 
kerke in Suid-Afrika is ' $\mathrm{n}$ goeie voorbeeld hiervan. Die vraag kom onvermydelik op of die afwesigheid van diepgaande teologiese besinning oor kulturele diversiteit en kontak binne ' $n$ postkoloniale horison van globalisasie nie hiertoe bydra nie. Hierdie artikel wil met die voorstel van ' $n$ Teologie van Interkulturaliteit reageer op hierdie brandende vraagstuk.

\section{KULTUUR EN TEOLOGIE: 'N NUWE AGENDA?}

Die aanname oor die afwesigheid van teologiese besinning oor kulturele diversiteit en interaksie moet uiteraard genuanseer word. Die oorskreiding van kulturele grense met die Evangelie was een van die grondliggende ervaringe van die Oer-Christelike kerk. Binne ' $n$ kort periode het dramatiese verskuiwings plaasgevind, byvoorbeeld van ' $n$ Oosterse na ' $n$ Westerse konteks, en van ' $n$ Aramees- na 'n Griekssprekende gehoor. Bybelboeke soos Handelinge en Efesiërs gee genoegsame getuienis van hierdie kulturele verwikkelinge.

Dit was veral die missionêre beweging wat die kerk met die uitdaging van kulturele verskeidenheid gekonfronteer het. Mens sou goedskiks drie momente in hierdie ervaring kan identifiseer. Die kontak van Westerse sendelinge met nie-Westerse kulture het ' $n$ tipiese kruis-kulturele dinamiek geskep waar die vreemdheid van die "ontvanger" kultuur meestal erg problematies vir die "oordrag" van die evangelie was. Waar hierdie uitwaartse beweging met die koloniale tydperk saamgeval het, is dit dikwels ook gekenmerk deur ' $n$ Westerse kultuur-imperialisme. Die postkoloniale fase het ' $n$ nuwe waardering vir die integriteit van die “Ander”-kulture gebring. In hierdie tweede moment is die realiteit van multikulturaliteit erken en het dit gelei tot die aandrang van outentieke kontekstuele teologieë wat kulturele eie-aard respekteer. Die ontwikkeling van ' $\mathrm{n}$ sogenaamde geglobaliseerde wêreld het die derde en huidige interkulturele fase ingelei waar die voortdurende verkeer en beïnvloeding tussen kulture die teologiese agenda vorm. Dis opvallend dat kultuur as onderwerp van teologiese besinning meestal stééds binne die missiologie voorkom. Hiermee word moeilik ontkom aan die assosiasies van 'n ongelyke ontmoeting.

Daar is egter enkele bemoedigende tekens dat sistematiese teoloë die onvermydelike en belangrike rol van kultuur by konstruktiewe refleksie begin verreken. Tanner (1997) maak gewag van kultuur as 'n "nuwe agenda"; Grenz en Franke (2001) van die 
“embedding context" van teologie. Schreiter (1997) verbind die kristallisering van die nuwe geglobaliseerde wêreld direk aan die imperatief van ' $\mathrm{n}$ interkulturele teologiese hermeneutiek. Dit is by hierdie werk watek wil aansluit en wat ek oordeel van besondere belang is vir die Suider-Afrikaanse konteks. Enkele realiteite maak hierdie besinning noodsaaklik. Die sosiale werklikheid is een van groeiende kontak, verkeer, en onderhandeling tussen mense van diverse kulturele agtergronde. Die kerklike horison is met die sogenaamde skuif na die Suide (cf. Jenkins 2002) soortgelyk globaal en multi-kultureel. Kerklike verdeeldheid in Suid-Afrika is dikwels gebaseer op ras- en kultuurverskeidenheid. Die kulturele gesig van die kerk as katoliek vra dringend om teoretisering.

As deel van hierdie taak is dit raadsaam om te nuanseer en te onderskei tussen Interkulturele Teologie en 'n Teologie van Interkulturaliteit. Waar eersgenoemde dui op die diskoersmatige, die ontmoeting tussen denksisteme, konsentreer laasgenoemde op die eksistensiële werklikheid, die kontak tussen mense. Wijsen (2001:221 ev) omskryf ' $n$ interkulturele teologie as 'n gesprek tussen lokale teologieë, maar laat ook die indruk dat dit die ervaringsmatige kontak tussen kulture insluit. Mens sou waarskynlik noukeuriger moet nuanseer. Dieselfde geld vir Küster (2005:429) se verstaan van Interkulturele Teologie wat hy as volg omskryf: "Inter-cultural theology explores the inter-confessional, inter-cultural and interreligious dimensions of the Christian Faith”. Die interaksie tussen uitdrukkinge van geloofsrefleksie en tussen mense van verskillende kulture, maar van dieselfde geloof, is nie dieselfde nie. Die gebrekkige ontwikkeling van kontekstuele teologieë in Suider-Afrika maak die eerste onderneming tans baie moeilik. Die vervreemding tussen gelowiges - selfs binne een konfessionele gemeenskap soos die Gereformeerde kerke - vra dringend na denke oor die grondslae van interkulturaliteit. Die artikel wil 'n bydrae lewer tot hierdie gesprek binne christelike teologie en die kerk.

\section{ELEMENTE VAN ' $N$ TEOLOGIE VAN INTER- KULTURALITEIT}

Die vraag moet onverwyld aangesny word wát tot die agenda van ' $n$ Teologie van Interkulturaliteit sou hoort. Wat is die fundamentele vrae wat geïdentifiseer en in behandeling geneem moet word? ' $\mathrm{n}$ Bekwame teoloog soos Schreiter (1997:28-45) fokus op die vraag van herme-neutiek en interkulturele kommunikasie, en identifiseer 
vrae na betekenis, waarheid, balans tussen verskille en eendersheid, en handeling ("agency”) as kardinaal. Hoewel hierdie wesentlike dimensies is wat hy bespreek, bly dit ' $n$ vraag of ' $n$ Teologie van Interkulturaliteit nie dieper behoort te reik as kommunikasie, sonder om die allerbelangrike rol van hermeneutiek te ontken nie.

My voorstel is dat vrae wat wentel rondom transendensie, gemeenskap en transformasie konstitutief behoort te wees vir ' $n$ Teologie van Interkulturaliteit. Anders gestel: godsbeskouing, ekklesiologie en spiritualiteit vorm die sentrale steunpunte van so ' $n$ konstruksie. Dit verg kort toeligting en verantwoording. Om die aanpak as teologies te kwalifiseer moet die godsvraag uitdruklik verreken word; méér nog, behoort dit bepalend te wees vir die besinning. Teologie se unieke bydrae tot die gesprek oor die uitdagings wat die kontak en verkeer tussen kulture binne ' $n$ geglobaliseerde era oproep, is juis om die finale horison van die werklikheid ter sprake te bring: God. Geen ander dissipline het hierdie taak nie. Hoe die verwysing na God funksioneer, sal later verduidelik word. Dit is die aanname van hierdie artikel dat die christelike God benaam moet word as trinitaries, as eksplisiete aanduiding van identiteit. Die trinitariese belydenis word dan ook by implikasie die raamwerk van waarheid (kyk Vanhoozer 2005:819, 821). Om konsekwent trinitaries te argumenteer, word produktiewe perspektiewe dan geopen op kerk en spiritualiteit, wat van sentrale belang is by interkulturaliteit'. ' $n$ Teologiese bydrae tot die uitdagings van interkulturaliteit, is nie net geïnteresseerd in effektiewe of suksesvolle kommunikasie nie, maar in die totstandkoming van gemeenskap tussen mense. Die kultureelspesifieke gelowige is in teologiese sin 'n "ekklesiale self” (Grenz 2005:96). Sonder transformasie, wat die wesentlike by spiritualiteit is (Sheldrake 2007:33), is dit nie moontlik nie. Hiermee word uitdrukking gegee aan die keer na ervaring wat die afgelope drie dekades so prominent na vore getree het. Om te besin vanuit die werklikheid van ' $n$ bepaalde God en die mens pertinent te verstaan as relasioneel en transformerend, kan teologies ' $n$ bydrae gemaak

1 Deur ' $n$ trinitariese godsbegrip te betrek by die debat rondom interkulturaliteit behels ' $\mathrm{n}$ bepaalde afgrensing. Die vraagstelling kan gekompliseer word deur verskillende godsbeskouinge te opper (vgl Schreiter 2005:28-31). Hierdie artikel verteenwoodig 'n christelik teologiese gesprek, en nie ' $n$ inter-religeuse nie. 
word tot die gesprek rondom interkulturaliteit binne 'n christelike raamwerk.

Deur godsbeskouing, ekklesiologie en spiritualiteit te identifiseer as sentrale boustene van ' $n$ Teologie van Interkulturaliteit is nie genoegsaam nie. Hierdie is die formele raamwerk, wat materiële presisering vra. Uit die aard van die multien interkulturele dinamika sou dit verantwoordbaar wees om andersheid ("otherness"), relasionaliteit en identiteit uit te lig. Die krisis, spesifiek binne die kerk, wentel om hierdie realiteite wat ' $n$ verskeidenheid van kulture oproep. ' $n$ Trinitariese Teologie van Interkulturaliteit hou die belofte in om nuwe en verreikende insigte te open. Hierdie voorstelle sal in die res van die artikel verder uitgewerk word.

\section{KULTUUR EN TRINITEIT IN RESENTE DISKOERS}

' $n$ Trinitariese benadering tot interkulturaliteit vra uiteraard ' $n$ kort weergawe van hoe die begrippe kultuur en triniteit aan die bod kom in ' $n$ kontemporêre vakkundige gesprek. In die volgende paragrawe word kortliks aandag gegee aan belangrike verskuiwings binne die twee diskoerse.

\subsection{Postmodernistiese fragmente oor kultuur}

Veral twee verwikkelinge staan uit in die huidige debat oor kultuur. Daar is ' $n$ opvallende wegbeweeg van modernistiese opvattinge oor kultuur, asook van die begrip multikulturaliteit; 'n meer postmodernistiese verstaan van kultuur en groter waardering vir interkulturaliteit kom voor.

Daar is geen enkele korrekte omskrywing van kultuur wat allerweë met konsensus gebruik word nie. 'n Definisie soos dié van Dahl (2004:6) - "culture as a shared set of basic assumptions and values, with resultant behavioural norms, attitudes and beliefs which manifest themselves in systems and institutions as well as behavioural patterns and non-behavioural items" - sou vandag moontlik slegs enkele kopknikke ontvang. Die vrae wat daaraan gerig kan word, soos byvoorbeeld, waar die elemente van dinamika, transformasie, en onderhandeling is, raak die basiese probleem aan van die herbesinning oor die aard van kultuur. Toenemend word ' $n$ ouer verstaan van kultuur as self-genoegsame, duidelik afgegrensde eenheid, wat intern konsekwent, homogeen en samehangend is en wat die sosiale orde stabiliseer, bevraagteken. Tanner (2007:531) dui 
die postmodernistiese sentimente aan as ' $n$ klem op interaktiewe prosesse, fragmentering, konflik, poreuse grense en hibriditeit. Die vraag kan selfs gevra word of die kategorie "kultuur" binne 'n nuwe denkhorison nog bruikbaar is. Abdallah-Pretceille (2006:479) stel voor dat daar eerder van "kulturaliteit" gepraat moet word om uitdrukking te gee aan die werklikheid van voortdurende verandering, assimilasie en weerstand binne kulture. Prominent in hierdie postmodernistiese benadering is ' $n$ waardering vir die betekenisskeppende funksie van kultuur; dit dra by tot die konstruksie van 'n wêreld en help identiteit vorm (Grenz \& Franke 2001:138). Vir Tanner (2007:527) gaan dit by kultuur om hierdie “meaning dimension of social action". So tree dan 'n aksent op die belangrikheid van waardes en simbole na vore, wat nie noodwendig integrerend werk nie, maar dikwels konflikterend.

' $n$ Postmodernistiese benadering tot kultuur het onvermydelik die kwessie van navorsing uitermate begin kompliseer. Hoe kultuurverskille aangebied word, het indringend onder die loep gekom. Kulturele antropologie se aandag is gevestig op metodologie, probleme van epistemologie, interpretasie en vorm van representasie (Marcus \& Fischer 1986:9). Die onderlinge verhouding van kennis, sosio-politieke mag en die representasie van die "Ander" het met ' $n$ felheid die akademie getref. Die koppeling van postmodernisme met ' $n$ postkoloniale antenna het die uitdaging net verder geïntensiveer. Wildburger (2004:105) maak met reg gewag van 'n postkoloniale navorsingsetiek. Nie net kristalliseer ' $n$ nuwe stel van navorsingsvrae nie, soos byvoorbeeld "wie definieer die navorsingsprobleem?", maar word die "ons-vs-die Ander" posisie verander na ' $n$ intersubjektiewe en samewerkende aanpak (Wildburger 2004:107).

Die tweede verskuiwing hang saam met 'n noukeuriger gebruik van terme. "Kruiskultureel" dra die gedagte oor van inbeweeg van een kultuur in die ruimte van die ander, 'n oordrag wat plaasvind en dan terugkeer na die oorspronklike posisie; dit het egter ook die konnotasie van a-simmetriese verhoudinge (Irizarry 2006:30). "Multikultureel" as beskrywing gee uitdrukking en erkenning aan diversiteit en pluraliteit. Daar is toenemend die vraag of multikulturaliteit nie net ' $n$ handhawing van die status quo is nie, en basiese werklikhede van ras, mag en bevoorregting ignoreer (Esterline 2006:17; Powell \& Sze 2004:2). Teenoor dié twee terme is "interkulturaliteit" ' $n$ kritiese en dinamiese term wat interaksie en kommunikasie tussen kulture aandui, en wat erns maak met die 
werklikheid van magsbalanse. Verder verreken dit die moontlikheid dat kulturele identiteit kan verander, en dat dit bevraagteken moet word (Powell \& Sze 2004:2; Abdallah-Pretceille 2006:476f). Irizarry (2006:30) som dit raak op: "In an intercultural experience no one is guaranteed that their cultural identities will remain the same throughout the engagement". In ' $\mathrm{n}$ postmoderne en postkoloniale moment is dié term klaarblyklik veel meer gepas.

\subsection{Nogeens: Trinitariese renaissance}

Dis waarskynlik passé om nogeens van die nuwe belangstelling in triniteit gewag te maak; dit het so wyd deel van teologisering geraak, dat die verwikkeling bykans nie meer vermelding nodig het nie. By wyse van 'n kort opgaaf kan kortliks op vier duidelike aksente gewys word, wat direk van toepassing is op die probleemstelling van die artikel.

Die God van die christelike geloof word eksplisiet geïdentifiseer as Vader, Seun en Heilige Gees. ' $n$ Hernude waardering het gekom in die twintigste eeu vir nie-generiese spreke oor God. In die christelike geloof staan ' $\mathrm{n}$ spesifieke God, met ' $\mathrm{n}$ unieke identiteit sentraal: ' $\mathrm{n}$ God wat een is, maar terselfdertyd wesentlik gedifferensieerd. Die God wat ons ontmoet in die openbaring is ' $\mathrm{n}$ trinitariese God.

Hierdie aksent het uiteraard gelei tot hernude refleksie oor die inhoud en formulering van die trinitariese belydenis as sodanig. Goeie oorsigte bestaan wat die historiese asook kontemporêre besinning aanteken (kyk bv. Grenz 2004 \& Kärkkäinen 2007). Opvallende tendense kom voor: kritiese vrae rondom Augustinus, besondere waardering vir die Kappadosiërs; vertrekpunte vanuit die meervoudigheid van die drie goddelike persone en die eenheid van God as teologiese opgaaf. Twee momente van die nuwere besinning is van besondere betekenis, ook vir hierdie artikel: die verhouding van die ekonomiese tot die immanente triniteit, en die formulering van 'n sosiale triniteit. Hoe God geopenbaar is in die heilsekonomie, is die grond en kriterium vir alle kennis van God self. So verkry die ekonomiese triniteit epistemiese voorkeur, en die immanente triniteit ontiese voorrang (vgl Sanders 2007). Die implikasie hiervan is duidelik: wat God van Homself bekend maak in die heilsgeskiedenis is wat Hy wesentlik ook is. Die belydenis oor drie persone moes onvermydelik lei tot ' $\mathrm{n}$ ontginning van verhoudingsmatigheid in die goddelike wese. Die formulering van 'n sosiale triniteitsleer is die 
natuurlike verwikkeling hiervan: God is gemeenskap in Sy ewige goddelike misterie (vgl Thompson 1997).

Van besondere belang in die sistematiese teologie is die aandrang dat die ganse christelike visie vanuit die werklikheid van hierdie trinitariese God bedink moet word. Triniteit is nie meer ' $n$ enkele klein afdeling binne die tradisionele godsleer nie, maar word die informerende en kontrolerende optiek vir besinning oor elke dimensie van die belydenis. As enkele voorbeeld kan gewys word op die onlangs verskene werk van Hunt (2005). Hierin toon sy aan dat die skeppingsleer, christologie, soteriologie, ekklesiologie, eskatologie en selfs die etiek, spiritualiteit en inter-religieuse dialoog trinitaries kan en moet bedink word. Wat sy hier behandel, is bloot ' $n$ goeie kompilatoriese voorbeeld waarmee verskeie vooraanstaande teoloë mee besig is: die ontwikkeling van 'n konsekwent trinitariese verwerking van die geloofsinhoude.

Die opwindende van die nuwe belangstelling in die triniteit is dat dit nie net ' $n$ ingekeerde dogmatiese aktiwiteit is nie, maar dat dit toepassing vind by van die mees aktuele kwessies van die samelewing. Daar word byvoorbeeld trinitariese perspektiewe geopen vir debatte oor ekonomiese etiek, geslagtelike gelykheid, en sosiale diskriminasie. Die Engelse gedenkbundel vir Moltmann God's Life in Trinity (Volf \& Welker 2006) - gee 'n goeie aanduiding van hierdie verwikkeling in die triniteitsteologie: byvoorbeeld vrae oor vrygewigheid, eiendom, gender en geregtigheid word bespreek aan die hand van 'n geloof in die Drie-enige God.

Die dinamika wat hier aanwesig is, is voor-die-hand-liggend: ' $n$ poging om transendensie te herwin binne besinning en om ' $n$ heuristiese raamwerk te vind vir komplekse vraagstukke. Om beide hierdie behoeftes met die triniteitsleer aan te spreek is insiggewend en moet as ' $n$ betekenisvolle kenmerk van die teologiese horison geregistreer word. Ten diepste word ' $n$ spesifieke verstaan van God as waarheid voorgestel en dan verder as van publieke betekenis ontgin.

Enkele vrae bly egter opduik: hoe funksioneer die trinitariese verbeelding retories, dit wil sê, hoe word die kategorie "God" aangewend, en hoe word die brug gebou van die godsleer na die ander kwessies? Anders gestel: hoe word trinitariese teologie verantwoordelik gedoen? Verwysings na God kan een van twee funksies vervul in 'n diskoers: óf God tree as Agent op, dit wil sê die 
handelende, óf Hy tree as Voorbeeld of Model op. Gedetailleerde trinitariese teologisering sal by beide onderskeid maak met verwysing na die drie Persone. Byvoorbeeld, die motief dat Christus Homself ontledig het, kan verstaan word as realistiese handeling of as simboliese voorbeeld.

By meeste trinitariese toepassings val 'n algemene kommerloosheid op oor die gevaar van syns-analogiese probleme. Volf (bv 1998:198 ev \& $213 \mathrm{ev}$ ) se werk is ' $\mathrm{n}$ belangrike uitsondering in hierdie verband; hy is akuut bewus van die probleme inherent aan ' $\mathrm{n}$ trinitariese aanpak. Die noodsaaklikheid en grense van die trinitariese verbeelding verdien meer aandag. Desnieteenstaande ' $n$ geregverdigde huiwering, is daar genoeg gronde vir ' $n$ omvattende trinitariese blik op die geloof en op aktuele sosiale kwessies: byvoorbeeld die doop in die naam van die trinitariese God, die skepping na die beeld van God, asook die bybelse motief van navolging van God gee 'n mandaat vir so 'n aanpak.

\section{KONTOERE VAN ' $N$ TRINITARIESE TEOLOGIE VAN INTERKULTURALITEIT}

\subsection{Triniteit en Interkulturaliteit?}

Teen hierdie agtergrond en verwikkelinge tree die vraag van ' $n$ trinitariese Teologie van Interkulturaliteit na vore. 'n Mens sou dit ook so kon verwoord: het die belydenis van God as Vader, Seun en Heilige Gees enige implikasie vir die problematiek onderliggend aan interkulturaliteit? In ooreenstemming met sentimente wat in die trinitariese Renaissance ingebou is, behoort die triniteit heuristies bevrugtend aangewend te kan word. Die uitdaging is om hierdie publieke betekenis van die trinitariese geloof argumentatief te kan aantoon.

' $n$ Voor-die-hand-liggende retoriese weg is om aan te sluit by die bybelse motief van navolging van God se karakter. By beide die $\mathrm{Ou}$ - en Nuwe Testament is die imitatio dei as etiese riglyn aanwesig (kyk Barton 2003:50-54; Meeks 1993:157-163). Om te vertrek van deugde as goddelike disposisies waaraan die mens deur genade deel mag kry (so ekspliseit by Cunningham 2008:167), open die weg om van ' $n$ bepaalde godsbeskouing te beweeg na ' $n$ bepaalde sosiale praktyk.

Waaraan die trinitariese belydenis oor God se wese uitdrukking aan gee, vra onmiddellik die aandag. Die omvang van die betekenis 
van die verhouding tussen die ekonomiese en immanente triniteit tree helder na vore. God is in Sy ewige wese die partikuliere en onderskeie bestaan van Vader, Seun en Heilige Gees. In hierdie ewige relasionele gemeenskap van onherleibare goddelike persone is Sy identiteit as God te vind. Wat hier noëties kristalliseer deur die openbaring is ' $n$ herdefiniëring van die tradisionele attribuut-tradisie wat geïnformeer is deur die Hellenisme. Om trinitaries te dink oor God se wese is ' $n$ nuwe uitdaging in die teologie (vgl Gunton 2002). In plaas van om te opereer met idees oor almag, alwetendheid, alomteenwoordigheid, onverander-likheid, vra ' $\mathrm{n}$ hele nuwe stel kategorieë om aandag, byvoorbeeld andersheid, relasionaliteit, gemeenskap, liefde. Dit is veral Zizioulas (2006:32-36) wat andersheid as intra-trinitariese kwaliteit oortuigend verwoord het. Andersheid is denkmatig so kardinaal dat hy dit tot ' $n$ ontologiese kategorie verhef, en vervolgens vind hy by die triniteit "the ontological ultimacy of otherness" (Zizioulas 2006:33). Nieortodokse tendense, byvoorbeeld Arianisme kon nie andersheid duld in die wese van God nie. Dit was die uitsonderlinge bydrae van die Kappadosiese Vaders dat hulle die drie hypostaseis as vertrekpunt geneem het in hulle beskouing van God. Hierdie klem op andersheid by Zizioulas is ' $n$ ontwikkeling in sy eie denke wat vroeër hoofsaaklik klem gelê het op 'n ontologie van gemeenskap. Hy beskou die triniteit pertinent as model vir die kerk "for the proper relation between communion and otherness" (Zizioulas 2006:4). Die klem op die relasionaliteit van God is waarskynlik die uitstaande insig van die nuwe belangstelling in die triniteit (Grenz \& Franke 2001:193). Die invloed van die postmoderne denke moet nie geringgeskat word in hierdie verwikkeling nie; teenoor ' $n$ modernistiese waardering vir verdeling en klassifikasie, is daar tans veel meer klem op interafhanklikheid (Cunningham 2003:189). Die ewige relasionaliteit van die christelike God roep ' $\mathrm{n}$ hele spektrum van assosiasies en perspektiewe op: die persoonsmatigheid van God, die reeks van verhoudinge, en die uitsonderlinge kwaliteit van die immanente relasies. Om gewag te maak van God as die skenkende, die verwelkomende, die gasvrye, is 'n uitvloeisel van hierdie relasionaliteit. Kreatiewe refleksies oor die ewige kommunikatiewe karakter van God (bv Migliore 2003:143) of oor Sy geregtigheid (bv Wolterstorff 2006:187) lê in die verlengde van die verhouding van die Vader, Seun en Gees tot mekaar. Die kulminasie van hierdie onderskeidinge kan niks anders wees die liefde van God nie. Omdat God ewiglik andersheid, relasionaliteit en gemeenskap in Sy wese 
het, is Hy liefde. Hy is dit in 'n ontologiese sin: "God is love as the relationship the Father, Son and Spirit are as persons in communion" (Schwöbel 1998:326). Slegs ' $n$ ontwikkelde triniteitsbeskouing kan konstituerend wees vir ' $\mathrm{n}$ teologiese verstaan van liefde. Dit is net ondenkbaar dat hierdie insigte oor God geen konsekwensies kan inhou vir sosiale verhoudinge nie.

Cunningham (2008:162f) se voorstel van sogenaamde "trinitarian virtues" kom goed hier te pas. Die drie deugde wat hy identifiseer - polifonie, partisipasie, en partikulariteit - kom as trinitariese openbaring aan die lig. Dat ' $n$ godsgeloof nuwe insigte kan open, word hier goed geïllustreer. Hierdie drie deugde gee gestalte aan die moontlikheid dat skynbare teenstrydighede tot ' $\mathrm{n}$ voller lewe kan lei; dat ' $n$ persoon se deelname aan ' $n$ ander se lewe nie gedoem is tot identiteitsverlies nie; en dat interafhanklikheid en verskille versoenbaar is. Die lewe in eenheid van die drie goddelike persone open hierdie nuwe synsmoontlikhede. Indiwidualiteit beteken nie onafhanklikheid nie; ko-habitering by ' $n$ ander se lewe bring nie identiteitsverlies mee nie; en verskeidenheid in eenheid bring nie ontwrigting van harmonie en skoonheid nie. Die teendeel is telkens waar.

Die misterie van die goddelike lewe openbaar nie net outentieke lewe nie; dit kom as etiese opgaaf na die skepping. Die problematiek van ' $\mathrm{n}$ multikulturele samelewing, soos byvoorbeeld Suider-Afrika, tree akuut na vore: die impuls tot isolasie, afskeiding, wegkeer, terug-trekking, onafhanklikheid, afkeer. Selde klink ' $n$ polifoniese skoonheid op. Die aktuele relevansie van 'n godsgeloof kan kwalik duideliker wees.

Deur die betekenisvolheid van ' $n$ bepaalde godsbeeld vir ' $n$ spesifieke sosiale horison aan te beveel, impliseer nie dat dit gedoen word sonder die wete van die probleme inherent aan die projek nie. Wat hier ter sake is, is om die praktiese en publieke betekenis van die trinitariese belydenis te ontgin. Wanneer ' $n$ uitstaande trinitariese teoloog soos Jenson (2004:414) sonder omhaal gewag maak van die "polity in God", die "eternal political life of God", die trinitariese lewe as "a space of moral action", omdat die Drie-enige God ' $n$ pluraliteit van sosiale persone is, duik die aktuele toepassing van hierdie idees onvermydelik op. Tanner (2004:321) waarsku tereg teen ' $n$ inflasie van verwagtinge van die progressiewe politieke potensiaal van die triniteit. Haar noukeurige betoog dat ' $n$ trinitariese godsbeeld net so misbruik kan word soos ongekwalifiseerde 
monoteisme is oortuigend. So is ook haar identifisering van die teologiese probleem: hoe die brug geslaan moet word tussen God en samelewing. Om egter die strategie om God as Model te gebruik af te wys, oortuig nie. Haar eie voorstel (Tanner 2004:328) dat mens moet dink in terme van "the economic Trinity as closing the gap by incorporating the human within it" hoef nie teenoor die modelstrategie te staan nie. God as referent kan verskillend verstaan word. Godsbeelde funksioneer as modelle wat impakteer op die mens se lewe; net so kan God ook verstaan word as Handelende Agent. Beide benaderings is geregverdig. Nuansering hoe die kategorie God binne ' $n$ diskoers (kan) funksioneer is die uitdaging aan die teoloog.

\subsection{Trinitariese Ekklesiologie en Interkulturaliteit}

Waar die samelewing faal met outentieke interkulturele verkeer, ontstaan die vraag na tekens van hoop om sinisme teen te werk. Hier tree die belangrikheid van ' $\mathrm{n}$ ekklesiologie na vore by ' $\mathrm{n}$ Teologie van Interkulturaliteit. Die kerk is die ruimte waar nuwe vorme van sosiale interaksie verrassende gestalte kry. As inklusiewe gemeenskap van mense van haas onversoenbare agtergronde verkry die kerk haar onvervangbare roeping in ' $n$ multi-kulturele samelewing. Die kerk kán dit wees, omdat sy 'n konkrete ikoon is van die Drie-enige God se werk en lewe.

Hierdie innige band tussen kerk en triniteit is ' $\mathrm{n}$ prominente bybelse aksent. Die doop as inisiasie tot ' $n$ nuwe gemeenskap geskied in die naam van die Vader, Seun en Heilige Gees. Die dopeling se nuwe identiteit word gevorm deur hierdie God en hierdie konkrete gemeenskap van mense. Die uitstaande metafore in die Skrif vir die kerk - volk van God, liggaam van Christus, tempel van die Gees - getuig dat die kerk hierdie God se werk is en onlosmaaklik aan Hom verbind is. Die Kerk is die herstelde beeld van God; as imago trinitatis is die kerk die unieke teken van die Vader, Seun en Heilige Gees.

Die ontwikkeling van ' $\mathrm{n}$ trinitariese ekklesiologie is ' $\mathrm{n}$ positiewe verwikkeling wat ' $n$ mens teëkom by ' $n$ groot aantal uitstaande toeloë van verskillende denominasionele agtergronde. Dit is byvoorbeeld opvallend in ' $n$ goeie oorsig van ekklesiologiese besinning in die die 20ste eeu soos dié van Kärkkäinen (2002) hoe nou kerk en triniteit verbind word. Daar is ' $n$ oortuiging dat die trinitariese begronding te lank agterweë gebly het, en dat die kerk se wese en identiteit op geen ander wyse gedink kan word nie. As 
teologiese werklikheid, moet kerk in terme van 'n spesifieke God verstaan word.

Waarskynlik die belangrikste uitvloeisel van ' $\mathrm{n}$ trinitariesbenaderde ekklesiologie, is die verstaan van kerk as communio, as gemeenskap. Dit bring ingrypende vordering op tradisionele aksente op kerk as instituut en as organisme. Die twintigste eeu het wye instemming gebring dat triniteit, ekumene en kerk as koinonia sáámhoort (Del Colle 2007:253). Om kerk primêr as nuwe gemeenskap te verstaan het vanselfsprekende relevansie vir ' $n$ multikulturele samelewing. Die kerk raak die alternatiewe ruimte waar al die patologieë van kulturele verskeidenheid in streng soteriologiese sin nuutgemaak kan word. Vervreemding maak plek vir versoening, vyandigheid vir gasvryheid, minagting vir waardering, diskriminasie vir diens. Migliore (2003:145) merk treffend op:

"In the eternal divine life, there is difference that does not divide, otherness that does not separate, and encounter that does not become opposition. The richness of the triune life is the basis of all genuine life in community".

Hierdie genesing en transformasie is moontlik omdat ' $n$ nuwe narratief - die verhaal van ' $n$ vreemde en sonderlinge God persoonlike en kol-lektiewe identiteit vorm. Die rol van gemeenskap by identiteitsvorming by die mens in die algemeen is van kardinale belang. Gemeenskappe met hul konstituerende verhale raak bepalende verwysingsraamwerke wat mense in staat stel om hul identiteit te ontwikkel (vgl Grenz 2003:253-260). Die kerk as getuienis van die lewe en werk van die Drie-enige God, stel mense van uiteenlopende kulture in staat om hul identiteit te verdiep. Nie net in hul verhouding met hierdie God nie, maar ook in hul verhoudinge met gelowiges van ander kulture vind hierdie verruiming plaas.

Hierdie aksent op gemeenskap vul eenheid as kenmerk van die kerk met ' $n$ baie spesifieke inhoud (vgl Meyer 1999:65-70). Allereers word die eenheid van die kerk teologies verstaan: dit word begrond deur die eenheid van God se wese. Dit plaas die eenheid van die kerk binne die horison van die heilshandelinge van God sodat gemeenskap ook die opgaaf tot versoening oproep. Omdat die klem op verhoudinge geplaas word, veranker dit die eenheid van die 
kerk in sigbaarheid. Vir ' $n$ interkulturele konteks is hierdie perspektiewe van dieallergrootste belang.

' $n$ Trinitaries-gefundeerde interkulturele ekklesiologie herdefinieer ook katolisiteit as tradisionele kenmerk van die kerk. Schreiter (1997:127-133) het dit goed raakgesien en verwoord. ' $n$ Hersiene en verbreede verstaan van katolisiteit is ' $n$ gepaste reaksie op die werklikheid van die kerk as interkulturele gemeenskap in 'n geglobaliseerde wêreld. Die implikasies van so ' $\mathrm{n}$ nuwe benadering kom volgens hom onder andere neer op veel groter openheid vir inkulturasie en vir die resepsie van die Evangelie wat ' $n$ "generosity" vereis ten opsigte van christelike identiteitsvorming. Dat ' $n$ verruimde begrip van katolisiteit ingrypend is, is hy deeglik van bewus; daarom pleit hy ook vir ' $\mathrm{n}$ wyer opvatting van waarheid. As katolisiteit verwys na "a wholeness of inclusion and fullness of faith in a pattern of intercultural exchange and communication" (Schreiter 1997:132), kan daar nie met net eenduidige beskrywings van waarheid opereer word nie, byvoorbeeld dat dit bloot referensieel is nie.

Waar die eenheid en die katolisiteit nuut verstaan word, raak die interkulturele kerk, en dan konkreet in die sin van die plaaslike gemeente, in die kragveld van die werk van die Heilige Gees ' $n$ eksperimentele ruimte waar verskille nie ontken, geminag word of tot konflik lei nie, maar waar verloste mense in hul wye eiesoortigheid nuwe uitdrukkings en vorme gee aan hul geloofspraktyke. Die nuwe karakter van die historiese moment, en die nuutheid van die uitdagings moet nie ontken word nie. Die voordeel van ' $n$ trinitariese raamwerk is dat daar teologiese hulpbronne na vore tree om hierdie uitdagings aan te spreek. Deurgaans in die heilsgeskeidenis was die Heilige Gees die bewerker van die verrassende, die nuwe. Bemagtig deur die Gees word kreatiewe en onvoorspelbare moontlikhede waar. ' $n$ Interkulturele ekklesiologie plaas 'n groot premie op hierdie pneumaties-geïnformeerde kreatiwiteit.

Na buite, missionaal gesproke, is die interkulturele kerk en plaaslike gemeente, ' $n$ baken van hoop en van weerstand binne ' $n$ gefragmenteerde samelewing. Identiteit moet bewustelik nie net een wees van eksperimentering nie, maar ook van verset. Die uitdaging om nie net vír die samelewing te wees nie, maar ook teenóór die samelewing, hoort tot die christologiese karakter van die kerk. Die kerk as fisiese draer van die kruis aanvaar hiermee ook konflik met 
' $n$ samelewing met diep ingeburgerde waardes, disposisies en praktyke. Die interkulturele kerk kan nie sonder konflik gevisualiseer word nie. As tempel van die Gees en as liggaam van Christus is die kerk tegelyk 'n ruimte van kreatiwiteit en van lyding.

\subsection{Trinitariese spiritualiteit en interkulturaliteit}

Houdings en ingesteldhede teenoor die kultureel Ander is beslissend vir sosiale praktyke, soos byvoorbeeld gasvryheid of afkeer. Hierdie basiese oriëntasie wat ten grondslag lê aan die inter-kulturele dinamika kan as spiritualiteit weergegee word. Hiermee word ' $\mathrm{n}$ grondnoemer geïdentifiseer wat aan ' $\mathrm{n}$ verskeidenheid disposisies uitdrukking gee. Dit verteenwoordig ' $n$ onontbeerlike element in ' $n$ Teologie van Interkulturaliteit, omdat dit deurslaggewend is by interkulturele kontak. Eenvoudig gestel: 'n bepaalde spiritualiteit bring ' $n$ bepaalde kwaliteit na die interkulturele verkeer. ' $n$ Teologiese bydrae tot die onderhawige onderwerp moet hieraan aandag gee.

Die sogenaamde keer na spiritualiteit (kyk Kourie 2006) van die afgelope drie dekades, wat op drastiese religieuse verskuiwings dui, het as byproduk groter akademiese verantwoording gebring ten opsigte van die beskrywing van die wesentlike van die fenomeen. Uitstaande teoretici soos Schneiders (2005:16), Waaijman (2000:6) en Sheldrake (2007:2, 32) is dit eens dat spiritualiteit as eksistensiële verskynsel dui op die ervaringsmatige, binne 'n verhouding van gerigtheid op ' $\mathrm{n}$ finale waarde, wat dinamies is en transformerend werk. Wanneer spiritualiteit só verstaan word, blyk die relevansie daarvan vir die vraag na 'n Teologie van Interkulturaliteit. By spiritualiteit word die geleefde werklikheid betrek, waar finale oortuigings ter sprake kom en wat identiteitsvormend werk.

Dis duidelik dat die werksomskrywing wat algemeen voorkom (vgl bv Perrin 2007:10) met christelike inhoud gevul moet word. Die finale waarde by ' $n$ christelike spiritualiteit is teïsties, en dan meer spesifiek trinitaries. Van die betekenisvolle konstruktiewe arbied lê juis hier waar die verhouding tussen teologie en spiritualiteit ondersoek word. Teoloë soos byvoorbeeld McIntosh (2005) en LaCugna \& Downey (1993), wat insiggewende werk gelewer het oor die verhouding tussen triniteitsgeloof en spiritualiteit, verdien noukeurige aandag. Wat hier ter sprake is, is niks minder nie as paideia, vorming deur die christelike God (Charry 1997:371). 
Die inhoudelike kontoere van hierdie vorming sluit aan by wat reeds oor die karakter van God gesê is. Die goddelike deugde kom as opgaaf na die mens. Soos daar by elke tipe spiritualiteit prominente en beheersende motiewe is, byvoorbeeld heiligheid en mistieke eenwording, so tree daar ook by ' $\mathrm{n}$ spiritualiteit van interkulturaliteit dominante temas na vore wat waardeer en gekoester moet word. So ' $n$ spiritualiteit toon sensitiwiteit vir andersheid, relasionaliteit en gemeenskap. Dit respekteer nie net alteriteit, verhoudinge en eenheid nie; maar situeer terselfdertyd ook geestelike groei binne hierdie raamwerk.

Spiritualiteit as transformasie is voortdurende selfwording onder invloed van die finale werklikheid. Die gelowige wat binne ' $n$ multikulturele sosiale bestel leef, reflekteer intensioneel iets van die lewe van die Drie-enige God deur die kultureel Ander se uniekheid hoog te ag, hom/haar op te soek, en verhoudinge op te rig. Binne ' $n$ nuwe interkulturele ruimte van wederkerigheid vind terselfdertyd selfbevestiging en selfverdieping plaas. Die self word bevestig en vergroot in gasvryheid teenoor die Ander. So word die gelowige " $n$ egte Katolieke persoon (Volf 2005:166). Die term "hybridity" wat wyd besig word in Postkoloniale Studies (kyk Ashcroft, Griffiths \& Tiffen 1995:183f,) kan met vrug hier gebruik word. Die kontak tussen kulture, selfs al is dit a-simmetries, is wedersyds en produktief. Wanneer gelowiges van verskillende kulture ontmoet is die verkeer verrykend.

Omdat multikulturaliteit ' $\mathrm{n}$ sosiale verskynsel is, ís ' $\mathrm{n}$ spiritualiteit van interkulturaliteit ' $\mathrm{n}$ politieke keuse. Te midde van vervreemding en fragmentering word verhoudinge en gemeenskap ' $n$ doelbewuste keuse. Dit is egter, en dis belangrik om daarop te let, ' $n$ keuse wat vanuit ' $n$ intieme verhouding met die Drie-enige God spruit. Interkulturele praktyke resoneer met ' $\mathrm{n}$ spesifieke geloofsbelydenis oor God. Die narratief van 'n selfskenkende en gasvrye God raak ' $n$ normatiewe ruimte vir christelike lewenspraktyk (Volf 2002:251). Die verweefdheid van godsgeloof en sosiale praktyk maak van 'n trinitariese spiritualiteit van interkulturaliteit ' $n$ tipiese uitdrukking van wat Sheldrake (2007:175) ' $\mathrm{n}$ krities-profetiese paradigma noem. Juis hierin, in die verbinding van die teologiese en sosiale, met presiese inkleding - trinitaries en interkultureel - lê dié spiritualiteit se vitaliteit en relevansie. Mook (2005:36-42) wys tereg op die jukstaposisie van nie-konformering en transformasie. Om dominante sosiale waardes en praktyke te 
weerstaan, is nodig om die moontlikhede van die geestelike reis te ontgin. Konformering kan die veranderende krag van God inhibeer. Sy reken tereg dat intensionele betrokkenheid by interkulturele kerke as "transformational spaces" (Mook 2005:40) kan God se krag vir die mens ontsluit. ' $n$ Spiritualiteit met ' $n$ openheid vir die misterie vir die vreemde God van die christelike geloof, en 'n gasvryheid teenoor die kulturele Ander, plaas die gelowige op die weg van ontdekking van verrykende nuwe ervarings.

\section{Literatuurverwysings}

Abdallah-Pretceille, M 2006. Interculturalism as a paradigm for thinking about diversity. Intercultural Education 17 (5), 475-483.

Ashcroft, B, Griffiths, G \& Tiffin, H (eds.) 1995. The post-colonial studies reader. London: Routledge.

Barton, J 2003. Understanding Old Testament ethics. Louisville: Westminster John Knox.

Case-Winters, A 2006. Multicultural theological education: On doing difference differently, in Esterline, D V \& Kalu, O U (eds.). Shaping beloved community: multicultural theological education. Louisville: Westminster John Knox, 43-55.

Charry, E T 1997. Spiritual formation by the doctrine of the trinity. Theology Today 54, 367-380.

Cunningham, D S 2003. The trinity in Vanhoozer, K J, The Cambridge companion to postmodern theology. Cambridge: Cambridge University Press, 186-202.

-, 2008. Christian ethics: The end of the law. New York: Routledge.

Dahl, S 2004. Intercultural research: The current state of knowledge. London: Middlesex University Business School. Discussion paper no 26.

Del Colle, R 2007. The church, in Webster, J, Tanner, K \& Torrance, I (eds.). The Oxford handbook of systematic theology. Oxford: Oxford University Press, 253.

Esterline, D V 2006. Multicultural theological education and leadership for a church without walls, in Esterline, D V \& Kalu, O U (eds.). Shaping beloved community: multicultural theological education. Louisville: Westminster John Knox, 15-27.

Grenz, S J 2003. Ecclesiology, in Vanhoozer, K J (ed.). The Cambridge companion to postmodern theology. Cambridge: Cambridge University Press, 252-268.

-, 2004. Rediscovering the triune God: the trinity in contemporary theology. Minneapolis: Fortress. 
-, 2005. The social God and the relational self: Towards a trinitarian theology of the Imago Dei, in Metzger, P L (ed.), Trinitarian soundings in systematic theology. London: T\&T Clark, 87-100.

Grenz, S J \& Franke, J R 2001. Beyond foundationalism: shaping theology in a postmodern context. Louisville: Westminster John Knox.

Gunton, C E 2002. Act \& being: Towards a theology of the divine attributes. Grand Rapids: Eerdmans.

Holder, A (ed.) 2005. The Blackwell companion to christian spirituality. Oxford: Blackwell.

Hunt A 2005. Trinity: Nexus of the mysteries of the christian faith. Maryknoll, NT: Orbis.

Irizarry, J R 2006. Towards an intercultural approach to theological education for ministry, in Esterline, D V \& Kalu, O U (eds.), Shaping beloved community: multicultural theological education. Louisville: Westminster John Knox, 28-42.

Jenkins, P 2002. The next christendom: The coming of global christianity. Oxford: Oxford University Press.

Jenson, R W 2004. Eschatology, in Scott, P \& Cavanaugh, W T (eds.), The Blackwell companion to political theology. Oxford: Blackwell, 407-420.

Kärkkäinen, V-M 2002. An introduction to ecclesiology: Ecumenical, historical \& global. Downers Grove: InterVarsity.

-, 2007. The trinity: Global perspectives. Louisville: Westminster John Knox.

Kourie, C 2006. The "turn” to spirituality. Acta Theologica Supplementum 8, 19-38.

Küster, V 2005. The project of an intercultural theology. Swedish Missiological Themes 93 (3), 418-432.

LaCugna, C M \& Downey, M 1993. Trinitarian spirituality, in Downey, M (ed.). The new dictionary of catholic spirituality, 968-982. Collegeville, Minn: Liturgical Press.

Marcus, G E \& Fischer, M M J 1986. Anthropology as cultural critique. Chicago: University of Chicago Press.

McIntosh, M A 2005. Trinitarian perspectives on christian spirituality, in Holder, A (ed) 2005. The Blackwell companion to christian spirituality. Oxford: Blackwell, 177-189.

Meeks, W A 1993. The origins of christian morality: The first two centuries. New Haven: Yale University Press.

Metzger, P L (ed.) 2005. Trinitarian surroundings in systematic theology. London: T\&T Clark.

Meyer, H 1999. That all may be one: Perceptions and models of ecumenicity. Grand Rapids: Eerdmans. 
Migliore, D L 2003. The communion of the triune God: Towards a trinitarian ecclesiology in Reformed perspective, in Alstone, W M \& Welker, M (eds.), Reformed theology: identity and ecumenicity, Grand Rapids: Eerdmans, 140154.

Mook, S L 2005. The transforming power of the interracial/intercultural church. The Journal of Pastoral Theology 15(2), 33-48.

Perrin, D B 2007. Studying christian spirituality. London: Routledge.

Powell, D \& Sze, F (eds.) 2004. Interculturalism: exploring critical issues. Oxford: Inter-Disciplinary Press.

Powell, D \& Sze, F 2004. Introduction, in Powell, D \& Sze, F (eds.) 2004. Interculturalism: exploring critical issues. Oxford: Inter-Disciplinary Press, $1-2$.

Sanders, F 2007. The Trinity, in Webster, J, Tanner, K \& Torrance, I (eds). The Oxford handbook of systematic theology. Oxford: Oxford University Press, 35-53.

Schneiders, S M 2005. Approaches to the study of christian spirituality, in Holder, A (ed.). The Blackwell companion to christian spirituality. Oxford: Blackwell, 15-33.

Sheldrake, P 2007. A brief history of spirituality. Oxford: Blackwell.

Schreiter, R J 1997. The new catholicity: Theology between the global and the local. Maryknoll, NY: Orbis.

-, 2005. The possibilities (and limitations) of an intercultural dialogue on God, in Jeanrond, W G \& Lande, A (eds.), The concept of God in global dialogue, Maryknoll, NY: Orbis, 19-31.

Scott, P \& Cavanaugh, W T (eds.) 2004. The Blackwell companion to political theology. Oxford: Blackwell.

Schwöbel, C 1998. God is love: The model of love and the trinity. Neue Zeitschrift für Systematische Theologie und Religionsphilosophie 40, 307328.

Tanner, K 1997. Theories of culture: A new agenda for theology. Minneapolis: Fortress.

-, 2004. Trinity, in Scott, P \& Cavanaugh, W T (eds.), The Blackwell companion to political theology. Oxford: Blackwell, 319-332.

-, 2007. Cultural theory, in Webster, J, Tanner, K \& Torrance, I (eds.). The Oxford handbook of systematic theology. Oxford: Oxford University Press, 527-542.

Thompson, $\mathrm{T} \mathrm{R}$ 1997. Trinitarianism today: doctrinal renaissance, ethical relevance, social redolence. Calvin Journal of Theology 32, 9-42.

Vanhoozer, K J 2003. The Cambridge companion to postmodern theology. Cambridge: Cambridge University Press.

-, 2005. Truth, in Vanhoozer (ed.), Dictionary for the theological interpretation of the Bible, Grand Rapids: Baker, 818-822. 
Volf, M 1998. After our likeness: The church as the image of the trinity. Grand Rapids: Eerdmans.

-, 2002. Theology for a way of life, in Volf, M \& Bass, D C (eds.), Practicing theology: beliefs and practices in christian life. Grand Rapids: Eerdmans, 245-263.

Volf, M \& Welker, M (eds.) 2006. God's life in trinity. Minneapolis: Fortress.

Waaijman, K 2000. Spiritualiteit: vormen, grondslagen, methoden. Kampen: Kok.

Webster, J, Tanner, K \& Torrance, I (eds.) 2007. The Oxford handbook of systematic theology. Oxford: Oxford University Press.

Wijsen, F 2001. Intercultural theology and the mission of the church. Exchange 30(3), 218-228.

Wildburger, E 2004. Decolonizing methodologies: Intercultural research ethics at stake, in Powell D \& Sze, F (eds.). Interculturalism: exploring critical issues. Oxford: Inter-Disciplinary Press, 105-109.

Wolterstorff, $\mathrm{N}$ 2006. Is there justice in the trinity?, in Volf, M \& Welker, M (eds.). God's life in trinity. Minneapolis: Fortress, 177-187.

Zizioulas, J D 2006. Communion \& otherness: Further studies in personhood and the church. London: T \& T Clark. 